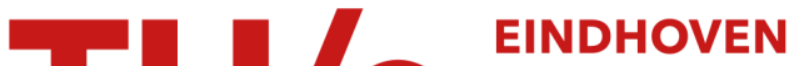 UNIVERSITY OF TECHNOLOGY
}

\section{In situ tissue engineering of functional small-diameter blood vessels by host circulating cells only}

\section{Citation for published version (APA):}

Talacua, H., Smits, A., Muylaert, D., van Rijswijk, J. W., Vink, A., Verhaar, M. C., Driessen - Mol, A., van Herwerden, L. A., Bouten, C. V. C., Kluin, J., \& Baaijens, F. P. T. (2015). In situ tissue engineering of functional small-diameter blood vessels by host circulating cells only. Tissue engineering. Part A, 21(19-20), 2583-2594. https://doi.org/10.1089/ten.TEA.2015.0066

DOI:

10.1089/ten.TEA.2015.0066

Document status and date:

Published: 01/10/2015

\section{Document Version:}

Publisher's PDF, also known as Version of Record (includes final page, issue and volume numbers)

\section{Please check the document version of this publication:}

- A submitted manuscript is the version of the article upon submission and before peer-review. There can be important differences between the submitted version and the official published version of record. People interested in the research are advised to contact the author for the final version of the publication, or visit the $\mathrm{DOI}$ to the publisher's website.

- The final author version and the galley proof are versions of the publication after peer review.

- The final published version features the final layout of the paper including the volume, issue and page numbers.

Link to publication

\section{General rights}

Copyright and moral rights for the publications made accessible in the public portal are retained by the authors and/or other copyright owners and it is a condition of accessing publications that users recognise and abide by the legal requirements associated with these rights.

- Users may download and print one copy of any publication from the public portal for the purpose of private study or research.

- You may not further distribute the material or use it for any profit-making activity or commercial gain

- You may freely distribute the URL identifying the publication in the public portal.

If the publication is distributed under the terms of Article $25 \mathrm{fa}$ of the Dutch Copyright Act, indicated by the "Taverne" license above, please follow below link for the End User Agreement:

www.tue.nl/taverne

Take down policy

If you believe that this document breaches copyright please contact us at:

openaccess@tue.nl

providing details and we will investigate your claim. 


\title{
In Situ Tissue Engineering of Functional Small-Diameter Blood Vessels by Host Circulating Cells Only
}

\author{
Hanna Talacua, MD,, ${ }^{1, *}$ Anthal I.P.M Smits, PhD, ${ }^{2, *}$ Dimitri E.P. Muylaert, MSc, ${ }^{3}$ Jan Willem van Rijswijk, ${ }^{4}$ \\ Aryan Vink, PhD, ${ }^{4}$ Marianne C. Verhaar, MD, PhD, ${ }^{3}$ Anita Driessen-Mol, PhD, \\ Lex A. van Herwerden, MD, PhD, Carlijn V.C. Bouten, PhD, ,,5 Jolanda Kluin, MD, PhD,,* \\ and Frank P.T. Baaijens, PhD ${ }^{2,5, *}$
}

Inflammation is a natural phase of the wound healing response, which can be harnessed for the in situ tissue engineering of small-diameter blood vessels using instructive, bioresorbable synthetic grafts. This process is dependent on colonization of the graft by host circulating cells and subsequent matrix formation. Typically, vascular regeneration in small animals is governed by transanastomotic cell ingrowth. However, this process is very rare in humans and hence less relevant for clinical translation. Therefore, a novel rat model was developed, in which cell ingrowth from the adjacent tissue is inhibited using Gore-Tex sheathing. Using this model, our aim here was to prove that functional blood vessels can be formed in situ through the host inflammatory response, specifically by blood-borne cells. The model was validated by implanting sex-mismatched aortic segments on either anastomoses of an electrospun poly( $\varepsilon$-caprolactone) (PCL) graft, filled with fibrin gel, into the rat abdominal aorta. Fluorescent in situ hybridization analysis revealed that after 1 and 3 months in vivo, over $90 \%$ of infiltrating cells originated from the bloodstream, confirming the effective shielding of transanastomotic cell ingrowth. Using the validated model, PCL/fibrin grafts were implanted, either or not loaded with monocyte chemotactic protein-1 (MCP-1), and cell infiltration and tissue development were investigated at various key time points in the healing cascade. A phased healing response was observed, initiated by a rapid influx of inflammatory cells, mediated by the local release of MCP-1. After 3 months in vivo, the grafts consisted of a medial layer with smooth muscle cells in an oriented collagen matrix, an intimal layer with elastin fibers, and confluent endothelium. This study proves the regenerative potential of cells in the circulatory system in the setting of in situ vascular tissue engineering.

\section{Introduction}

$\mathbf{T}$ HERE IS A clear clinical demand for suitable, artificial, small-diameter $(\varnothing<6 \mathrm{~mm})$ blood vessels, in particular for lower limb peripheral artery disease with an overall prevalence estimated to be in the range of $3-10 \% .{ }^{1,2}$ Current artificial small-caliber vessels have poor patency rates compared with their living counterparts, which is inherently due to their nonadaptive constitution. Tissue engineering has been proposed to overcome these shortcomings by delivering living small-diameter grafts. ${ }^{3,4}$ However, traditional tissue engineering approaches comprise lengthy and costly in vitro procedures. In situ tissue engineering is emerging as a promising alternative, in which an acellular bioresorbable synthetic graft is implanted, allowing the body to populate the scaffold with host cells and develop extracellular matrix while the scaffold is degraded. ${ }^{5}$ This approach is built on the notion that inflammation is not merely a detrimental response to biomaterials, but when harnessed properly, can be exploited to induce a natural regenerative response.$^{6-8}$ By omitting time-consuming cell expansion and bioreactor phases, this method can deliver cost-effective, off-the-shelf available grafts. ${ }^{6}$

Recent studies following the in situ tissue engineering principle have demonstrated colonization and subsequent remodeling of a biodegradable synthetic graft into functional

\footnotetext{
${ }^{1}$ Department of Cardiothoracic Surgery, University Medical Center Utrecht, Utrecht, The Netherlands.

${ }^{2}$ Department of Biomedical Engineering, Eindhoven University of Technology, Eindhoven, The Netherlands.

Departments of ${ }^{3}$ Nephrology and Hypertension and ${ }^{4}$ Pathology, University Medical Center Utrecht, Utrecht, The Netherlands.

${ }^{5}$ Institute for Complex Molecular Systems, Eindhoven, The Netherlands.

*These authors contributed equally to this study.
} 
neoarteries in various animal models. ${ }^{9-13}$ However, the cellular and molecular mechanisms underlying this functional regeneration remain elusive. ${ }^{4,14}$ An inflammation-mediated response has been suggested, comprising an initial rapid recruitment of immune cells to the scaffold, followed by an influx of tissue cells that remodel the graft into a native-like artery. ${ }^{15}$ Monocyte chemotactic protein-1 (MCP-1) has been identified as one of the key mediators in this process, and local release of exogenous MCP-1 from biodegradable scaffolds was shown to enhance de novo tissue formation. ${ }^{15}$

To translate preclinical results to human application, it is essential to recognize and predict regenerative processes (cell colonization and tissue development) representative for the human situation. From previous small animal studies employing degradable and nondegradable grafts, it is clear that transmural migration is a predominant source of macrophages as well as $\alpha$-smooth muscle actin ( $\alpha$-SMA)-expressing cells in rodents. ${ }^{16-18}$ Furthermore, transanastomotic ingrowth of mature endothelial cells (ECs) and smooth muscle cells (SMCs) was identified as the predominant source of tissue cells in the rodent model. ${ }^{19}$ However, given the fact that transanastomotic endothelialization in humans is restricted to the immediate perianastomotic region, the question arises how predictive these model-dependent processes are for the clinical situation, especially considering that vascular prostheses for humans often require extensive anatomic lengths. ${ }^{20,21}$ Moreover, this suggests that physiological remodeling of a graft in humans is heavily dependent on the contribution of circulating cells.

Therefore, our aim was to prove that functional blood vessels can be formed in situ through the host inflammatory response solely by circulating cells. To isolate the role of blood-borne cells in the regenerative process, we employed a more predictive rat model, in which the graft is isolated from surrounding tissues, both transmurally and transanastomotically. To preclude cell ingrowth from the adjacent tissue, highly porous electrospun poly( $\varepsilon$-caprolactone) (PCL) tubes were shielded by impenetrable Gore-Tex sheet material on both anastomoses and enclosing the adventitial side of the PCL scaffold over the entire length. To enhance rapid cell recruitment from the circulation, we incorporated fast-releasing MCP-1 into our scaffold using fibrin gel. Grafts were implanted as abdominal aortic interposition grafts in rats and were explanted at different time points in the remodeling cascade.

We hypothesized that (i) extracellular matrix-producing cells can be recruited from the circulation and that (ii) increased early monocyte recruitment to the graft by MCP-1 has a positive effect on long-term tissue remodeling and regeneration.

\section{Materials and Methods}

\section{Experimental animals}

Seventy-six healthy Sprague-Dawley rats, 250-300 g, were used, purchased from Harlan Laboratories. Each animal was fed ad libitum and was housed in groups in an environment maintained at room temperature for $24 \mathrm{~h}$ a day and with a 12-h light-12-h dark cycle. Two studies were performed; Study 1 was dedicated to validate the model, and Study 2 was dedicated to investigate the effect of MCP-1 in the scaffold. In Study 1 , Gore-Tex shielded grafts $(n=12)$ were compared with grafts without shielding $(n=12)$ (Fig. 1A-C). To study general cell infiltration in both groups over time, grafts were explanted at 1 day $(n=2), 3$ days $(n=2), 1$ week $(n=2), 2$ weeks $(n=2)$, and 3 months $(n=4)$. To specifically study the efficacy of the model in transanastomotic shielding, a sexmismatch experiment was performed, in which sections of male rat aorta were interpositioned proximally and distally to the graft in female rats, either shielded or unshielded with Gore-Tex ( $n=12$ per group) (Fig. 1D, E). These grafts were explanted after 1 or 3 months ( $n=3$ per group, per time point) for fluorescent in situ hybridization (FISH) analysis.

Study 2 was dedicated to study the effect of MCP-1, comparing fibrin-seeded grafts with incorporated MCP-1 $(n=20)$ versus fibrin-seeded controls $(n=20)$. All grafts in this study group were shielded with Gore-Tex. Grafts were explanted at 1 and 3 days, 1 and 2 weeks, and 3 months ( $n=4$ per time point). All procedures were performed in accordance with and approved by the Institutional Animal Care and Use Committee of the University of Utrecht, The Netherlands.

\section{Scaffold fabrication}

Electrospun (PCL) tubular scaffolds were manufactured and provided by Xeltis BV. In brief, PCL (Purasorb; Purac Biochem) was dissolved in chloroform at $20 \%(\mathrm{w} / \mathrm{w})$ and driven through a horizontally fixed nozzle at high voltage $(15 \mathrm{kV})$ toward a grounded rotating cylindrical copper target (Ø $2 \mathrm{~mm}$ ) at $15 \mathrm{~cm}$ distance. The resulting tube diameter, wall thickness, and average fiber diameter were determined with scanning electron microscopy (SEM; Quanta 600F, Fei). The materials were sterilized by gamma irradiation. Before implantation, the PCL tube was cut to size and the vessel wall was impregnated with fibrin gel $(5 \mathrm{U} / \mathrm{mL}$ thrombin $+5 \mathrm{mg} / \mathrm{mL}$ fibrinogen; Sigma). Depending on the test group, MCP-1 (4 $\mu \mathrm{g} / \mathrm{mL}$; Chemicon) was added to the fibrin solution. To measure the release rate of the MCP-1 from the graft, a cumulative leakage experiment was performed in vitro. For this, MCP-1-loaded scaffold samples were incubated in culture medium (RPMI-1640; Sigma) supplemented with $10 \%$ (v/v) fetal bovine serum (FBS Gold; PAA Laboratories) over a period of 7 days. At each time point $(0,0.75,1.5,3,8,24,48,72,120,168 \mathrm{~h})$, all supernatant was collected, replaced with fresh medium, and samples were stored at $-80^{\circ} \mathrm{C}$ until further analysis. MCP- 1 content was determined cumulatively using a human ELISA kit, according to the manufacturer's protocol (RayBiotech) $(n=3)$.

\section{Surgical procedure}

Before implantation, graft composites were prepared depending on the study group. To shield the electrospun grafts, an end-to-end anastomosis was made to a $4 \times 10 \mathrm{~mm}^{2} \mathrm{im}$ penetrable Gore-Tex strip (Preclude Pericardial Membrane; Gore Medical) using 10-0 interrupted sutures distally and proximally of the electrospun tube. Additionally, Gore-Tex was wrapped around the PCL in samples, creating an impenetrable outer layer (Fig. 1A-C). For the FISH experiments, sex-mismatched segments of aorta were interpositioned on the proximal and distal anastomoses between the native aorta and the graft (Control group, $n=3$ per time point; Fig. 1D) or Gore-Tex (Test group, $n=3$ per time point; Fig. 1E). Animals were anesthetized using isoflurane gas. Once adequate 

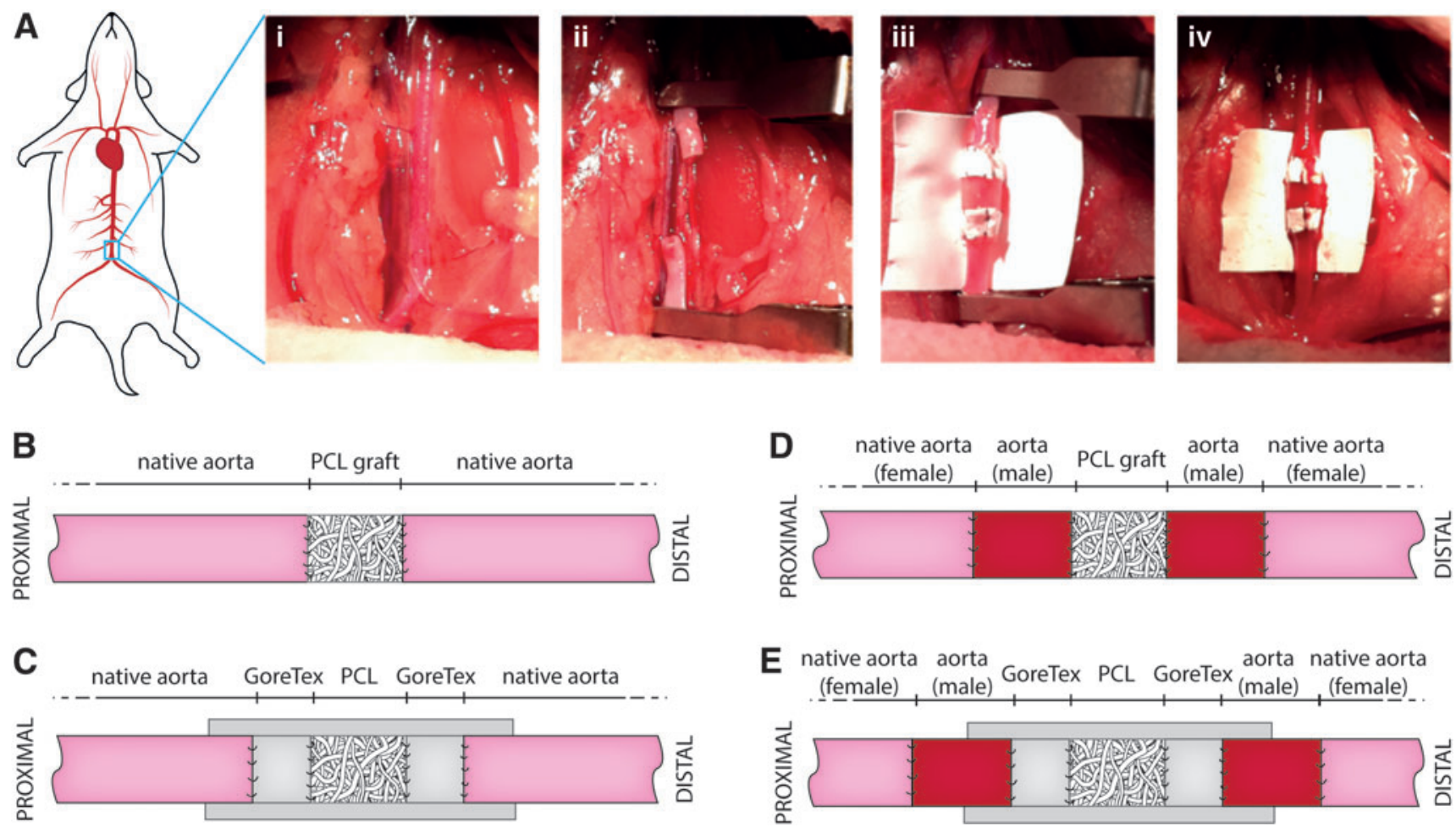

FIG. 1. Implantation procedure and experimental groups. (A) Camera microscopy images of the graft implantation with, in bright white, the Gore-Tex sheet. The aorta before (i), after transection (ii), after implantation of the graft (iii), and directly after removing the vascular clamps (iv). (B-E) Schematic representation of the experimental groups in Study 1, with the shielded grafts $(\mathbf{C})$ versus unshielded control $(\mathbf{B})$ and the sex-mismatched shielded graft $(\mathbf{E})$ versus the unshielded control (D). Color images available online at www.liebertpub.com/tea

anesthesia was achieved, a midline laparotomy was performed and the abdominal viscera were lateralized for exposure of the abdominal aorta and the inferior vena cava. After separation of the aorta from the inferior vena cava and surrounding tissue, the segment of the abdominal aorta between the renal arteries and the aortic bifurcation was occluded with microvascular clamps. The aorta was transected and the graft composite was introduced with end-to-end anastomosis performed at both the proximal and distal ends using interrupted sutures. After removing the vascular clamps, the pulsatile flow was confirmed in the aorta distal to the graft (Fig. 1A). The abdomen was closed in two layers. Immediately after implantation, all scaffolds were exposed to arterial hemodynamic conditions. There was no heparin administration during or after surgery. Animals recovered on warmed pads to promote blood flow through the grafts. Before rats returned to their cages, they were assessed for evidence of hind limb paralysis or acute graft thrombosis. Postoperative buprenorphine was given intraperitoneally.

At termination, animals were anesthetized using isoflurane. Tubes were dissected free from surrounding tissue. The Gore-Tex on the outer layer was opened and the PCL graft was carefully explanted. All explants were examined with immunohistochemistry. In Study 2, two explants per time point were additionally analyzed with quantitative polymerase chain reaction (qPCR) to determine the expression of genes involved in the inflammatory response. Furthermore, blood samples were collected and analyzed with ELISA to determine systemic protein levels of MCP-1 in the blood serum (Supplementary Data).

\section{Immunohistochemistry}

Explants were fixed in formalin $10 \%$ before pre-embedding in $1 \%(\mathrm{w} / \mathrm{v})$ agar (Eurogentec), followed by embedding in paraffin. Consecutive 4- $\mu \mathrm{m}$ sections were stained with Mayer's hematoxylin and eosin, Verhoeff van Gieson, and $0.1 \%$ $(\mathrm{w} / \mathrm{v})$ Sirius red F3B (Gurr BDH) in saturated picric acid solution, respectively. Immunohistochemical stainings were performed on 4- $\mu \mathrm{m}$ sections after deparaffinization and dehydration. Sections were stained for myeloperoxidase (A398, 1:2000, MPO; Dako), CD68 (1:400, MCA341GA; Serotec), CD163 (1:75, MCA342GA; Serotec), CCR7 (Cell Applications, CG1678, 1:15000), CD34 (R\&D Systems, AF4117, 1:100), ( $\alpha$-SMA; Sigma, A2547, 1:32,000), and Von Willebrand factor (vWF; Dako, A0082, 1:1600). All antibodies were diluted in PBS/BSA/Azide. Following deparaffinization, antigen retrieval was performed in citrate (For CD68, CCR7, and MPO), pepsin (CD163), or EDTA (vWF) before blocking with $10 \%$ normal goat serum ( $\alpha$-SMA and CCR7) or Ultra V block (MPO; Thermo Scientific). Sections were blocked for endogenous peroxidase when a horseradish peroxidase (HRP)-conjugated secondary antibody was used. Appropriate BrightVision signal amplification was used for labeling of primary antibody binding sites: poly AP anti-mouse for $\alpha$ SMA, poly HRP anti-mouse (CD68 and CD163), and poly HRP anti-rabbit (CCR7, MPO, and vWF) (Immunologic). Slides were subsequently incubated with liquid permanent red substrate-chromogen (Dako) or diaminobenzidine substratechromogen (Sigma) and counterstained with Mayer's hematoxylin. Slides were dehydrated in alcohol changes and 
coverslipped using pertex. Double-label immunohistochemistry for aSMA and $\mathrm{VWF}$ was performed after EDTA antigen retrieval by incubating sections for $1 \mathrm{~h}$ at room temperature with a mix of 1:32,000 mouse anti- $\alpha$-SMA and 1:1600 rabbit anti-vWF antibodies. The sections were then incubated with anti-mouse Alexa Fluor 488 and anti-rabbit Alexa Fluor 555-conjugated secondary antibodies (1:200; Invitrogen) for $30 \mathrm{~min}$. Cell nuclei were counterstained with 4',6-diamidino-2-phenylindole (DAPI).

\section{Quantitative histologic and immunohistological analysis}

Two investigators, who were blinded to the investigated groups and the time point of explantation, independently conducted the analysis. Sections were photographed using a Nikon E800 microscope with ACT-1 software. Wall thickness and lumen diameter were measured manually under a $2 \times$ objective lens. Wall thickness was measured in two sections of each graft and in four locations per section. The lumen diameter was measured in two sections of each graft and in two directions per section. Cellularity was studied under high-power magnification (high-power field [hpf], 40× objective lens; area comprising $0.034 \mathrm{~mm}^{2}$ ), with cell sizes being comparable between groups. The total number of cells in four random hpf areas per PCL tube was manually counted using ImageJ software. Quantification of aligned collagen was performed with picrosirius red stains and circularly polarized light. Stained sections were digitally photographed and converted into gray value images and regions of interest (ROIs) were drawn lining the graft. The average gray value per ROI was calculated using ImageJ software. A quantitative analysis of the immunopositive cells of each stained slide was performed at four random hpfs. The portion of area staining positively for the marker within the four hpfs was counted and summed for each image. The mean of the sums for four high-power images was then calculated for each sample. Area of positive staining was measured as a percentage of the total from binarized images.

\section{Fluorescent in situ hybridization}

To identify X- and Y-chromosomes, FISH was performed on fresh, sectioned paraffin sections using Rat idetect Chr X FISH Probe Green and Chr Y FISH Paint Probe Red (ID Labs, IDRF1067 and IDRR1070, respectively). Following deparaffinization, slides were pretreated with $0.2 \mathrm{~N} \mathrm{HCl}$ for $20 \mathrm{~min}$ at room temperature, citrate buffer ( $\mathrm{pH} \mathrm{6.0)}$ for $20 \mathrm{~min}$ at $100^{\circ} \mathrm{C}$, and digested with $0.1 \%$ proteinase $\mathrm{K}$ for $10 \mathrm{~min}$ at $37^{\circ} \mathrm{C}$. After dehydration in graded ethanol, $7.5 \mu \mathrm{L}$ of probe mixture was added. Sections were then denatured for $5 \mathrm{~min}$ at $69^{\circ} \mathrm{C}$, cooled on ice for $5 \mathrm{~min}$, and hybridized overnight at $37^{\circ} \mathrm{C}$ in a ThermoBrite. The next day, slides were washed in $0.4 \times \mathrm{SSC} /$ $0.3 \% \mathrm{NP}-40$ at $73^{\circ} \mathrm{C}, 2 \times \mathrm{SSC} / 0.1 \% \mathrm{NP}-40$ at room temperature, and $2 \times \mathrm{SSC}$ for 2,1 , and $5 \mathrm{~min}$, respectively. After washing, the sections were counterstained with DAPI, dehydrated, and mounted in Vectashield (Vectorlabs, H-1000). For quantification of the FISH results, at least 30 images per sample were analyzed by two investigators blinded to the experimental group, sample location, and time of implantation.

\section{Statistical analysis}

Statistical differences were determined using two-way ANOVA with time and test factor as the variables, with
Bonferroni post-tests to compare the means per time point using GraphPad Prism software. $p<0.05$ was considered statistically significant.

\section{Results \\ Grafts are constructed from porous electrospun PCL and dense Gore-Tex}

SEM analysis showed the dense microstructure of the Gore-Tex, with an internodal distance $<1 \mu \mathrm{m}$. In contrast, the PCL graft was highly porous with interconnected pores and an average fiber diameter of $9 \mu \mathrm{m}$ (range 8.4-9.7 $\mu \mathrm{m}$ ) (Fig. 2A, B). The inner diameter of the graft was $\sim 2 \mathrm{~mm}$ with an average wall thickness of $275 \mu \mathrm{m}$ (range 210$340 \mu \mathrm{m})$. Grafts were seeded with a fibrin gel with or without MCP-1. In vitro leakage experiments revealed a burst release of MCP-1 within the first $3 \mathrm{~h}$, after which the release gradually leveled off (Fig. 2C).

\section{Gore-Tex shielding led to a significant reduction of cell ingrowth from neighboring tissues}

All grafts remained patent and there were no signs of stenosis or thrombosis in all groups studied. Lumen diameter and wall thickness remained constant throughout the whole study ( $1.8 \mathrm{~mm} \pm 0.1$ and $385 \mu \mathrm{m} \pm 108$, respectively), with no signs of intimal hyperplasia or aneurysms. Macroscopically, granulation tissue was seen on the adventitial side of Gore-Tex sleeves (Fig. 3A, B, D, E). No cell infiltration into the dense adventitial sleeve was detected at any time point. Adventitial Gore-Tex shielding led to a significant reduction in total cellularity at all intervals compared with unshielded controls, with the largest difference at day 1 and day 14 (Fig. 3C).

For the FISH experiments, sections were taken from five different locations in the graft as well as the native (female) aorta and the implanted male segment (as indicated in Fig. 4) and analyzed for the presence of Y-chromosome using FISH. In the Control group, the average fraction of male cells detected in the graft was $37.4 \% \pm 12.1 \%$ and $43.1 \% \pm 9.8 \%$ after 1 and 3 months, respectively. Moreover, after 3 months of implantation, the distribution of male cells was homogenous throughout all sections of the Control group, with an average of $44.1 \% \pm 14.5 \%$ (Fig. 4A). In contrast, in the Test group, the fraction of male cells detected in the graft was severely limited, with an average of $9.4 \% \pm 3.2 \%$ and $10.1 \% \pm 7.7 \%$ after 1 and 3 months, respectively. There were no marked differences between the different locations in the graft (Fig. 4B). After 3 months, the native (female) aorta contained on average $38.1 \% \pm 9.3 \%$ male cells in this group, indicating a comparable migration of male cells to unshielded tissues compared with the Control group.

These results demonstrate effective isolation of the graft using Gore-Tex sheathing in this rat model, both transmurally and transanastomotically.

\section{MCP-1 recruits immune cells in the early inflammatory phase}

Cells penetrated immediately after implantation through the entire thickness of the PCL in all grafts (Fig. 5A-C). Directly after implantation, mainly neutrophilic granulocytes infiltrated all grafts, with a significant increase in 


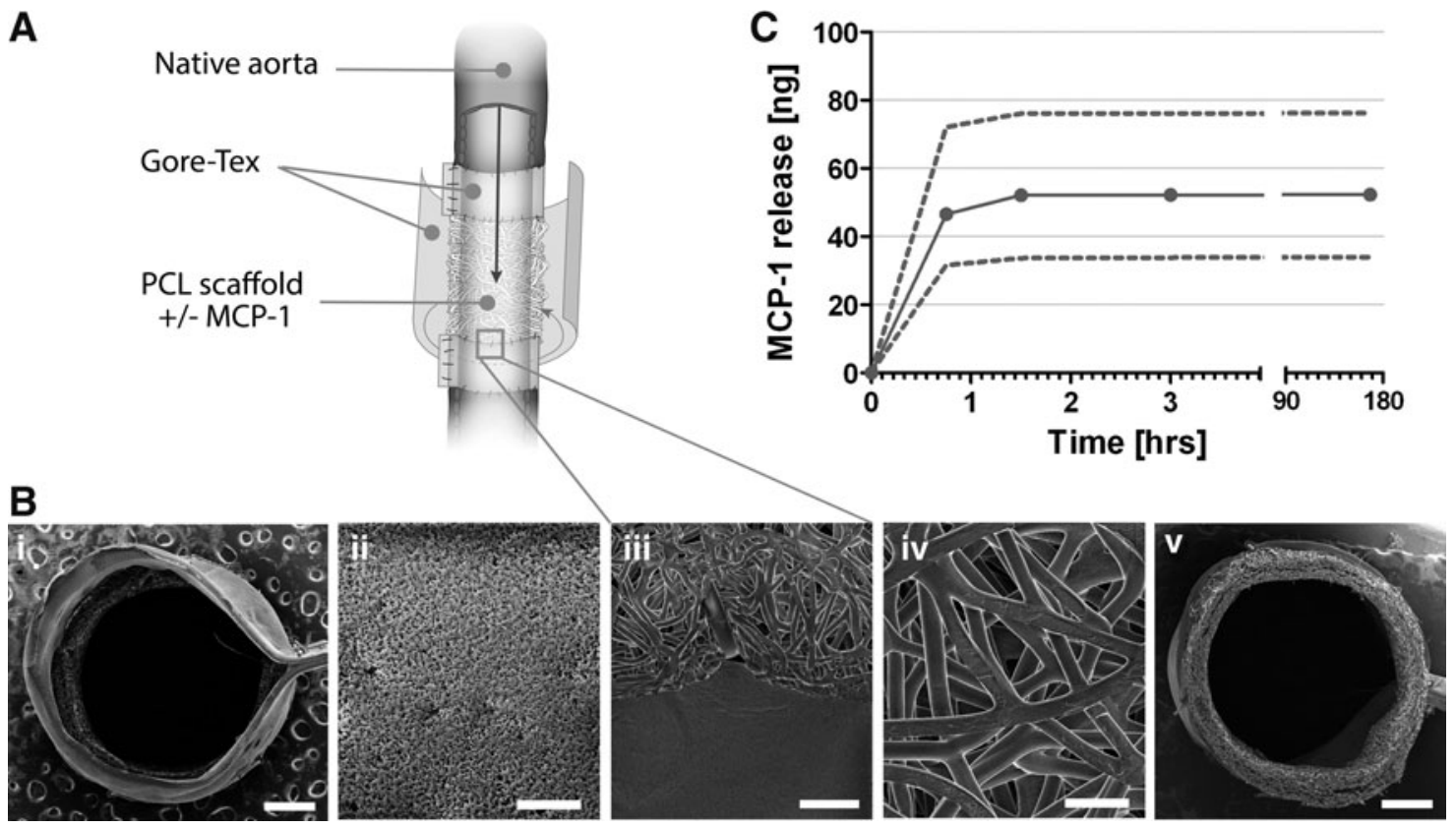

FIG. 2. Graft composition. Schematic representation of the monocyte chemotactic protein-1 (MCP-1)-loaded graft (A) with scanning electron microscopy images (B) showing a transection (i), the luminal surface of the Gore-Tex (ii), the Gore-Tex anastomosed to the poly(E-caprolactone) (PCL) (iii), and the luminal surface (iv) and transection of the porous PCL scaffold (v). (C) MCP-1 release curve as determined in vitro. Scale bars represent $500 \mu \mathrm{m}$ (i and v), $40 \mu \mathrm{m}$ (ii and iv), and $100 \mu \mathrm{m}$ (iii).

overall cell infiltration in the MCP-1 group compared with the control group at day 1 (Fig. 5D). There was a marked increase in $\mathrm{CD}^{+} 8^{+}$macrophage infiltrates in the MCP-1 and control group up to day 7 and day 14, respectively, with an even distribution throughout the graft. At day 7, the concentration of macrophages was significantly higher in the MCP-1 group compared with the control group. After the first 2 weeks, macrophage numbers gradually decreased in both groups with a significantly higher macrophage concentration in the MCP-1 group after 3 months (Fig. 5E). In both groups, macrophage giant cells were seen. Macrophage subtypes were characterized by CCR7 (M1) and CD163
(M2) expression. Surprisingly, CD163 ${ }^{+}$cells were detected very sparsely $(<1 \%)$. CCR7 expression was detected, but only a small fraction of the CCR7 staining double-stained positive for the pan-macrophage marker, CD68.

\section{Initial MCP-1 release results in enhanced tissue formation in the healing phase}

A progressive increase in $\mathrm{CD} 34^{+}$cells was observed in both groups, with no significant differences between groups up to day 14 (Fig. 6A, B). At day 84, the expression of CD34 was significantly higher in the MCP-1 group compared with
A
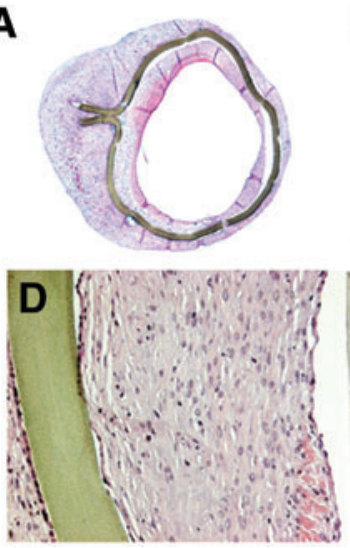

B
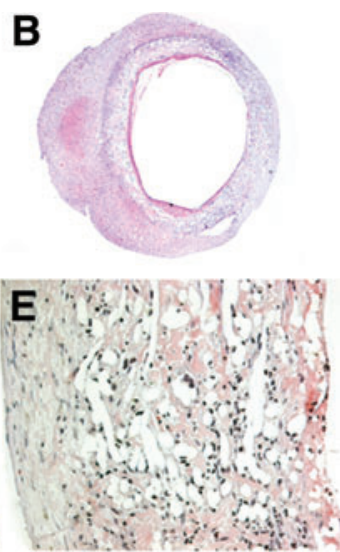

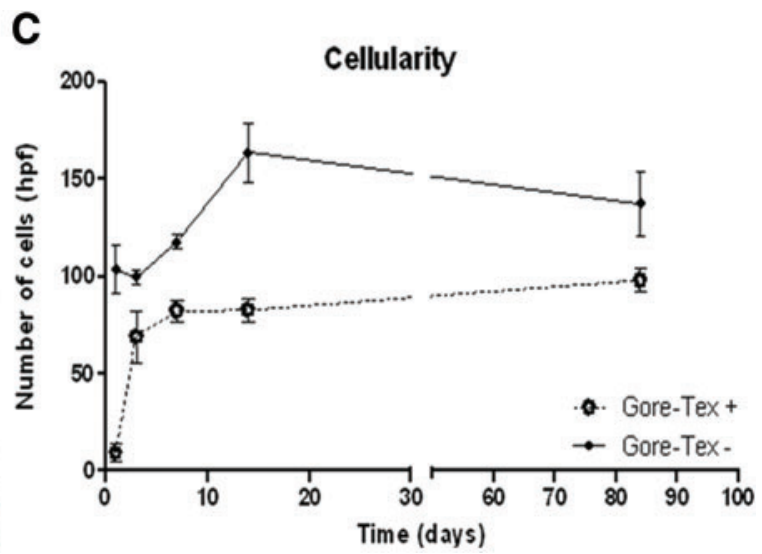

FIG. 3. Efficacy of transmural isolation. Scaffold cellularity of the shielded (A, D) versus nonshielded grafts $(\mathbf{B}, \mathbf{E})$. Cellularity decreased significantly in the grafts shielded with Gore-Tex when compared with the control group ( $98 \pm 6$ cells per high-power field [hpf] vs. $137 \pm 17$ cells per hpf, $p=0.03$ at 84 days), with the largest differences at day 1 ( $9 \pm 4$ cells per hpf vs. $103 \pm 12$ cells per hpf) and day 14 ( $82 \pm 6$ cells per hpf vs. $163 \pm 15$ cells per hpf) (C). Color images available online at www.liebertpub.com/tea 
A Control group

FIG. 4. Efficacy of transanastomotic isolation. Schematic representation of the graft composition and the results of the fluorescent in situ hybridization analysis for the unshielded Control (A) and shielded Test (B) group. Blue lines indicate the approximate locations of the analyzed sections. Red staining indicates the presence of Y-chromosome; cell nuclei are in blue (DAPI). Quantification of the staining reveals that transanastomotic cell ingrowth of male cells into the graft is effectively blocked in the Test group, while male cells are homogeneously distributed in the Control group. DAPI, 4',6diamidino-2-phenylindole. Color images available online at www.liebertpub .com/tea

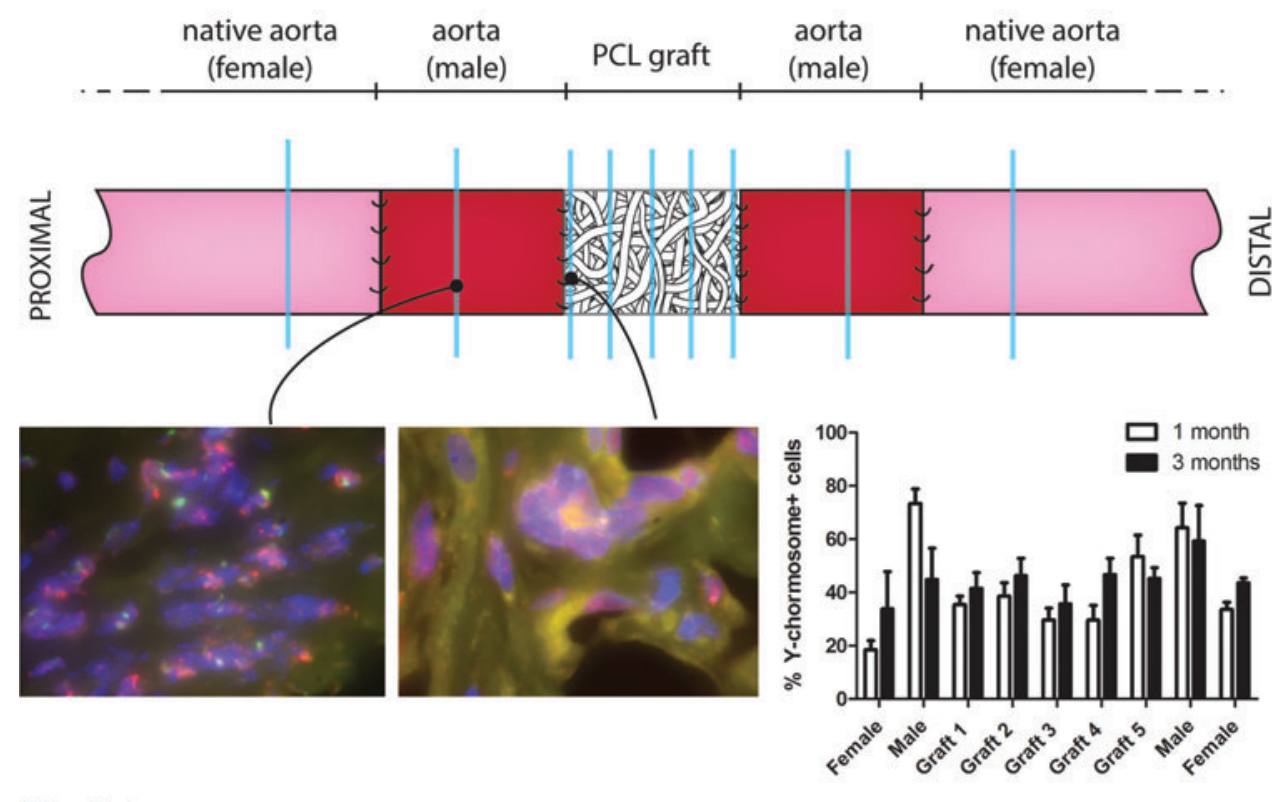

B Test group

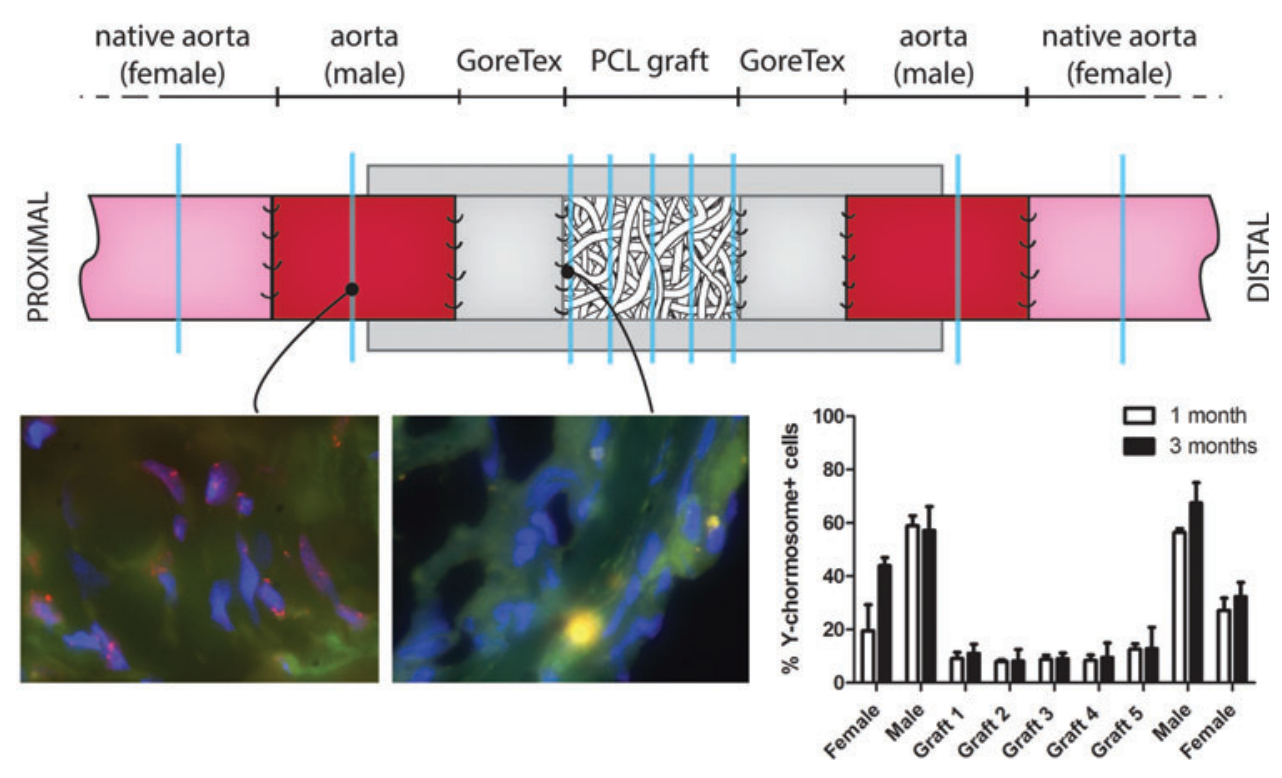

the control group. For $\alpha$-SMA expression, no significant differences were detected between groups for all time points (Fig. 6C, D). In both groups, the first $\alpha-\mathrm{SMA}^{+}$cells were detected at day 7. After 3 months, the myofibroblast population formed a circumferentially oriented neointima layer of SMCs under an endothelium in both groups (Fig. 6C). vWF staining revealed no significant differences between groups, with first evidence of ECs in the grafts at day 7 in both groups. Small patches of vWF-expressing cells lined the lumen, growing more confluent through week 2, before reaching a fully confluent monolayer at 3 months (Fig. 7JL). This was similar in both the MCP-1 group and the control group. At day 14, the first signs of collagen fibers were detected in both groups. After 3 months, circumferentially orientated bundles of collagen fibers were found lining the endothelial and outer layers of the graft, with more loose fibers toward the center of the wall (Fig. 7A-F). Aligned collagen was markedly increased after 3 months in both groups, with a significantly higher expression of aligned collagen in the MCP-1 group compared with the control group (Fig. 7M). In the MCP-1 group, first signs of elastin were seen in the Verhoeff van Gieson-stained slides in three of four rats after 84 days. In the control group, only one of four rats stained positive (Fig. 7G-I).

\section{Myofibroblasts do not originate \\ from endothelial-to-mesenchymal transdifferentiation}

All explants were analyzed for occurrence of endothelialto-mesenchymal transdifferentiation (endoMT) using immunofluorescent double staining of vWF and $\alpha$-SMA. No colocalization of vWF and $\alpha$-SMA was detected in any of 
A

No MCP-1

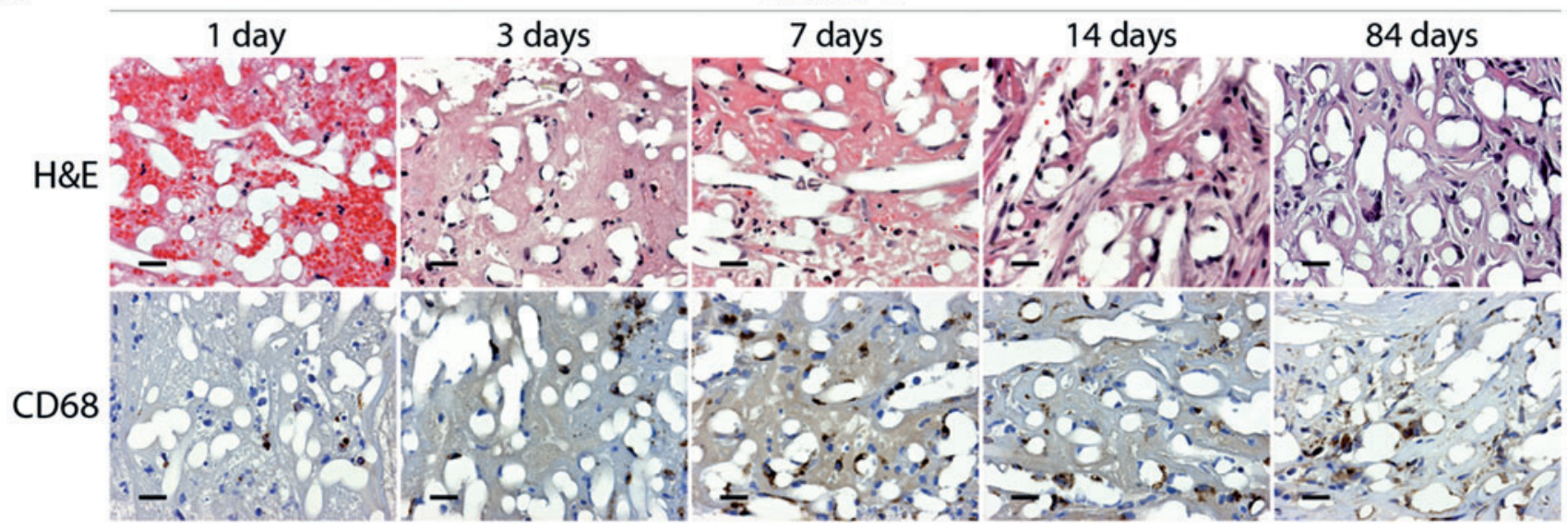

B

$+\mathrm{MCP}-1$

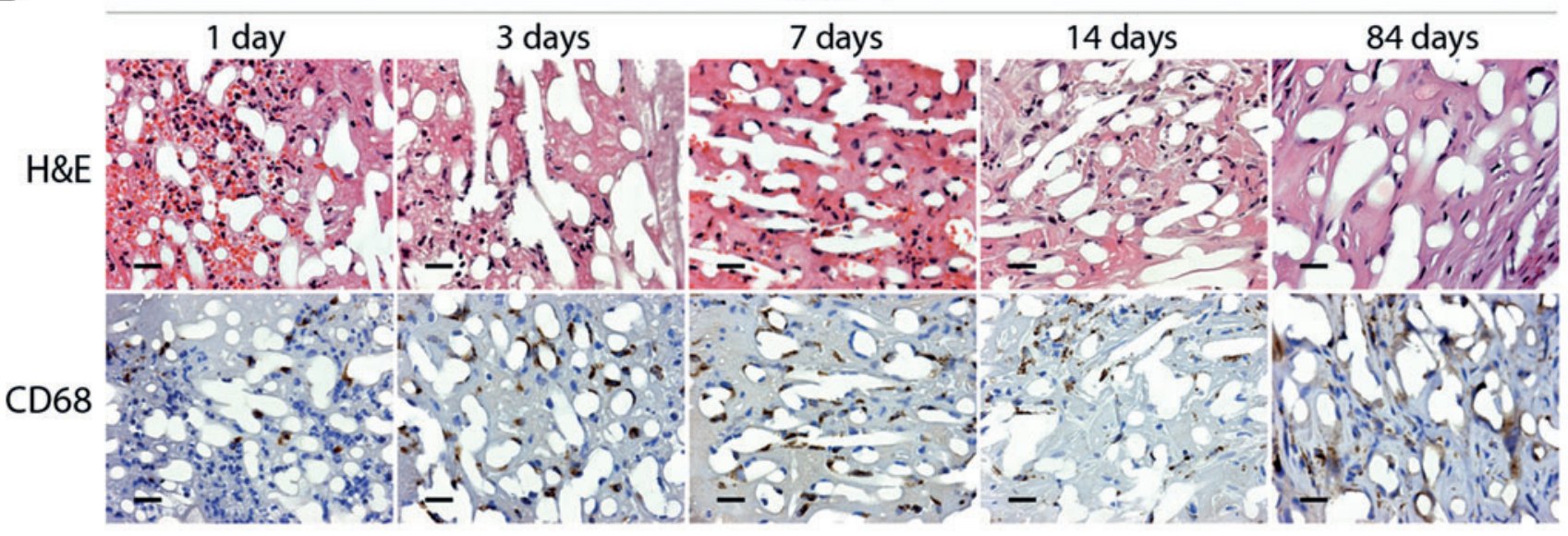

C
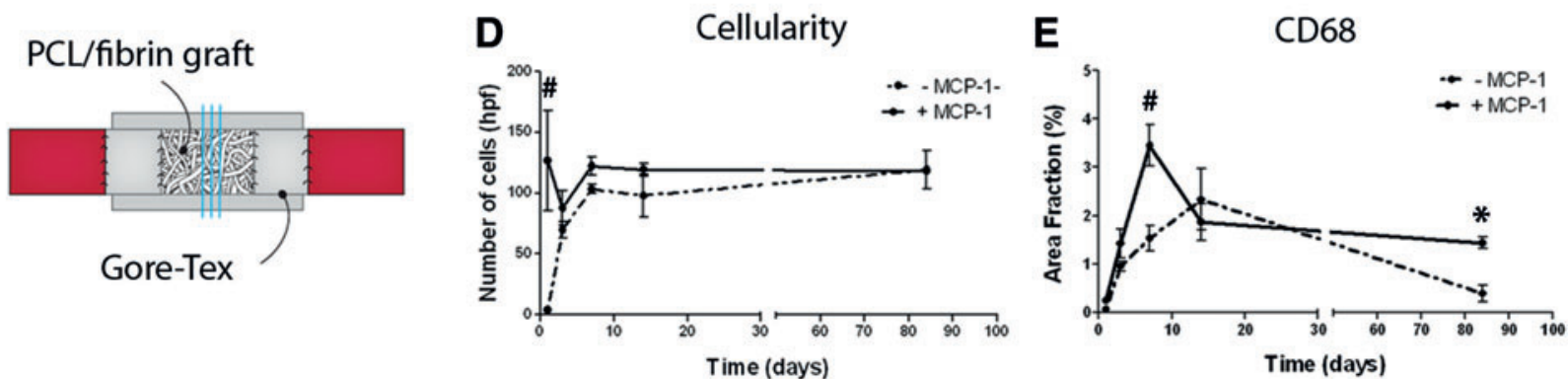

FIG. 5. Infiltration of immune cells. Histological evaluation on transverse sections of the center part of the PCL grafts (C), without and with MCP-1, explanted at days 1, 3, 7, 14, and 84 (A, B). The MCP-1 group displayed an immediate peak in overall graft cellularity at day 1 with significantly more cells compared with the control group (127 $\pm 40 \mathrm{vs}$. $4 \pm 2$ per hpf) (D). The percentage of $\mathrm{CD} 8^{+}$macrophages rapidly increased in the first 2 weeks, with a significantly higher concentration in the MCP-1 group compared with the control group at day 7 (33.2 \pm 4.7 vs. $15.3 \pm 2.7$ per hpf) and day 84 (14.9 \pm 0.2 vs. $5.6 \pm 4.1$ per hpf) (E). PCL fibers are visible in white. Scale bars represent $20 \mu \mathrm{m} .{ }^{*} p<0.001,{ }^{*} p<0.05$. Color images available online at www.liebertpub.com/tea

the explants of all time points, apart from a single cell showing colocalization of vWF and $\alpha$-SMA at the 14-day time point, indicating possible endoMT (Fig. 8).

\section{Discussion}

In situ tissue engineering of vascular grafts using synthetic scaffolds could deliver an off-the-shelve alternative to current vascular prostheses. In the context of clinical translation, we aimed to achieve an early attraction of circulating cells into a graft releasing MCP-1, using a novel rat model that prevents transanastomotic pannus overgrowth, as well as periadventitial ingrowth. Our results demonstrate that (i) extracellular matrixproducing cells can be recruited from the circulation and that (ii) increased early monocyte recruitment to the graft by MCP1 has a positive effect on long-term tissue remodeling and regeneration. Grafts underwent extensive cellularization by blood-derived cells, followed by tissue formation throughout 
FIG. 6. Infiltration of tissue cells. Histological evaluation of transections of the center part of the grafts demonstrates an increase in $\mathrm{CD}_{3} 4^{+}$cells over time in both groups, with a significantly elevated CD34 expression in the MCP-1 group at day $84(0.5 \pm 0.1$ vs. $0.2 \pm 0.01$ per hpf $)(\mathbf{A}, \mathbf{B})$. First $\alpha$-smooth muscle actin $(\alpha$-SMA) expression was detected at day 7 in both groups, forming an organized medial layer at 3 months follow-up (C). (D) High-magnification images of $\alpha$-SMA expression at day 14 , revealing $\alpha$-SMA ${ }^{+}$cells aligned with the PCL fibers, visible in white. Scale bars represent $50 \mu \mathrm{m}(\mathbf{A}, \mathbf{C})$ and $20 \mu \mathrm{m}$ (D). ${ }^{\#} p<0.001$.

the entire PCL graft, with all grafts remaining patent up to 3 months follow-up, without signs of aneurysms or intimal hyperplasia. Driven by early MCP-1 release, our remodeled synthetic graft showed several similarities to the native aorta after 3 months in vivo; the intimal layer with ECs lining the lumen, with early signs of a developing elastic lamina, and a medial layer consisting of SMCs in an aligned collagen matrix.

Ingrowth of host cells into vascular implants in rodent models is typically dominated by two mechanisms: transmural (mainly macrophages and $\alpha$-SMA-expressing cells) and transanastomotic infiltration (ECs and SMCs). ${ }^{16-19}$ The infiltration of cells through these routes is typically rapid and progressive and may obscure any contribution of fallout healing when using these animal models. However, the consistent observation that transanastomotic cell ingrowth, in particular, is limited in humans, makes that such rodent models may have limited predictive value for the clinical outcome, and the importance of a transanastomotic isolation model has been advocated previously. ${ }^{20,21}$ Moreover, since recruitment of blood-derived cells represents a valuable target for colonization of acellular grafts, this study was specifically aimed at isolating the role of circulating cells in the regenerative process (fallout healing) of a degradable vascular graft from transmural and transanastomotic events. The impermeable circumferential Gore-Tex sheathing as applied in the current study effectively isolated the periadventitial foreign body response from the porous PCL graft, preventing the excessive infiltration of $\alpha-\mathrm{SMA}^{+}$cells. In addition, we constrained progressive transanastomotic overgrowth using dense anastomotic Gore-Tex patches.

Gore-Tex is a type of expanded polytetrafluoroethylene (ePTFE), which has been used extensively in vivo for several decades. When employed as vascular grafts, varying endothelial outgrowth rates have been reported, ranging from virtually absent up to as high as $0.2 \mathrm{~mm} /$ day, depending on the model and materials used. ${ }^{22,23}$ Recently, a vascular loop graft model was proposed to overcome the limited space in the infrarenal rat aorta, employing lengthy ePTFE segments to shield transanastomotic ingrowth. ${ }^{21}$ However, cell overgrowth on Gore-Tex substrates is known to be highly dependent on the microstructure of the material used. Golden et al. demonstrated pore size-dependent healing of ePTFE grafts in a baboon model and they suggest a sharp threshold of pore size (intermodal distance between
30 and $60 \mu \mathrm{m}$ ) below which healing is abrogated in this animal model. ${ }^{24}$ Based on these reports, we opted for a type of Gore-Tex with extremely low porosity (internodal distance $<1 \mu \mathrm{m}$ ), which has shown to hamper tissue integration as it does not facilitate cell adhesion on its surface. ${ }^{25}$ Consequently, this would provide a sufficient barrier to isolate the porous PCL graft from the native artery, even over a small distance. The FISH analysis of sex-mismatched implants confirms that the Gore-Tex shielding effectively hampered transanastomotic ingrowth in our model, despite the limited width of the barriers. To the best of our knowledge, this is the first small animal model to effectively hamper both transmural and transanastomotic cell ingrowth to study purely the role of circulating cells, which is important for clinical translation and personalized application, for example, through preoperative boosting of specific cell populations in the circulatory system.

The most obvious contribution of circulatory cells to the regenerative process is attributed to peripheral immune cells. It is well recognized that monocytes and macrophages are the predominant effector cells mediating wound healing and repair in response to injury or infection. ${ }^{8,26,27}$ Monocyte and macrophage trafficking was shown to be dependent on MCP-1 and its primary receptor, CCR2 ${ }^{28,29}$ Exogenous MCP-1 delivery has been shown to increase monocyte/ macrophage recruitment and induce angiogenesis. ${ }^{30}$ Moreover, the use of MCP-1 in our scaffolds was motivated by previous findings demonstrating an enhanced secretion of MCP-1 by bone marrow-derived mononuclear cells when in interaction with immune cells. ${ }^{15,31}$ MCP-1 is a potent chemoattractant of various types of immune cells and, consequently, the burst release of MCP-1 in the present study (Supplementary Fig. S1; Supplementary Data are available online at www.liebertpub.com/tea) resulted in an increased early influx of leukocytes. This was also reflected in gene expression data (Supplementary Fig. S2), leading to improved tissue formation in the later stage. Prolonged upregulation of MCP-1 has been related to systemic complications, such as fibrosis and atherosclerosis. ${ }^{32}$ Therefore, we opted for a rapid release of MCP-1 from our scaffold to induce a favorable initial cellular response. The MCP-1 dose was determined from previous in vitro experiments. ${ }^{33}$ No systemic upregulation of MCP-1 was detected in the peripheral blood of the rats, despite peak measurements at day 1 (Supplementary Fig. S1).

FIG. 7. Tissue organization. Implanted grafts show similarities to the native rat aorta after 84 days. Collagen (PSR staining, polarized light) content in grafts without MCP-1 (A), grafts with MCP-1 (B), and in a native rat aorta (C). Collagen (PSR staining, confocal microscopy) in grafts without MCP-1 (D), grafts with MCP-1 (E), and in a native rat aorta (F). Elastin in grafts without MCP-1 (G), grafts with MCP-1 (H), and in a native rat aorta (I). Endothelial cell (EC) lining (von Willebrand factor) in grafts without MCP-1 (J), grafts with MCP-1 $(\mathbf{K})$, and native rat aorta $(\mathbf{L})$. Collagen alignment was significantly higher in the $+\mathrm{MCP}-1$ group after 84 days $(21 \pm 2.9$ vs. $11.9 \pm 1.7$ area fraction per hpf $)(\mathbf{M})$. Smooth muscle cell lining in the graft (N) and native aorta (O). Scale bars represent $500 \mu \mathrm{m}(\mathbf{A}-\mathbf{C}), 100 \mu \mathrm{m}$ (D-F), $500 \mu \mathrm{m}(\mathbf{N}), 200 \mu \mathrm{m}$ $(\mathbf{O})$, and $20 \mu \mathrm{m}(\mathbf{G}-\mathbf{L})$. Arrows indicate elastin fibers $(\mathbf{H}) .{ }^{\#} p<0.001$. 
A

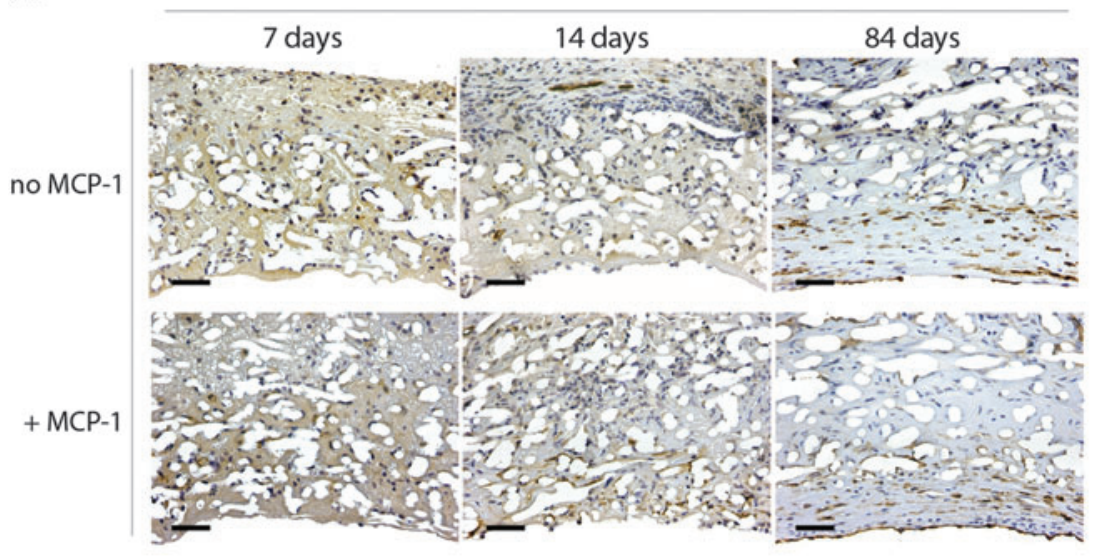

C

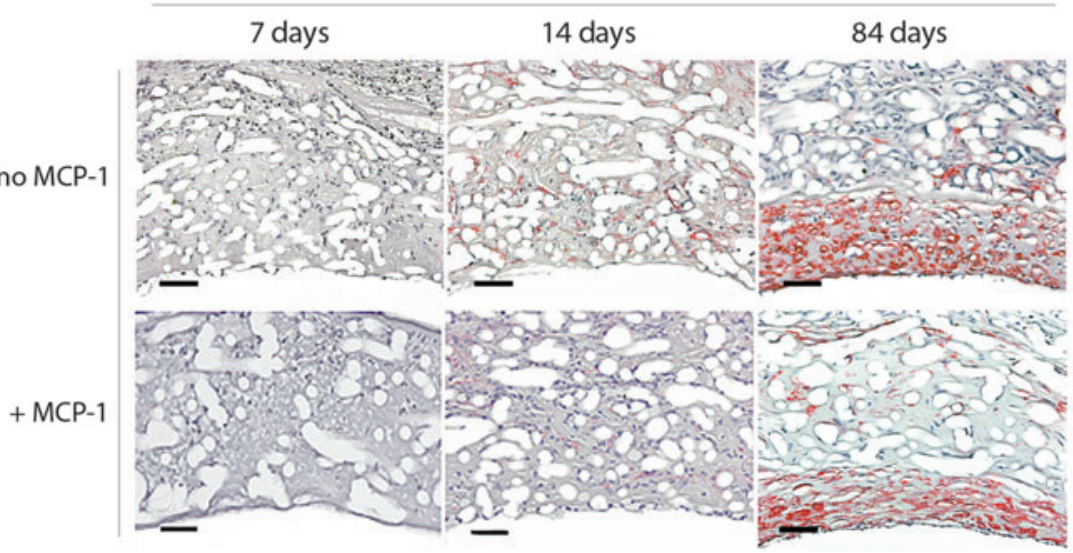

B

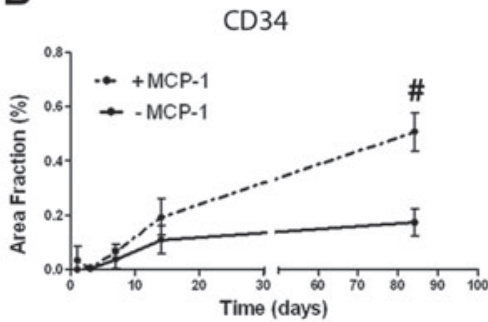

D

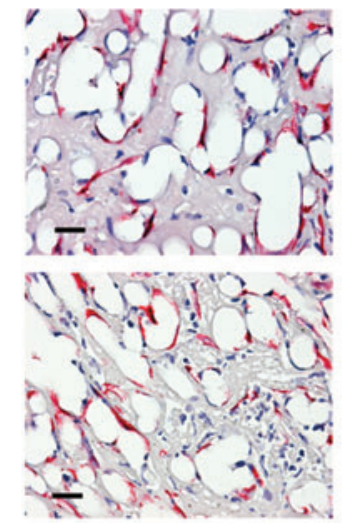

FIG. 6.
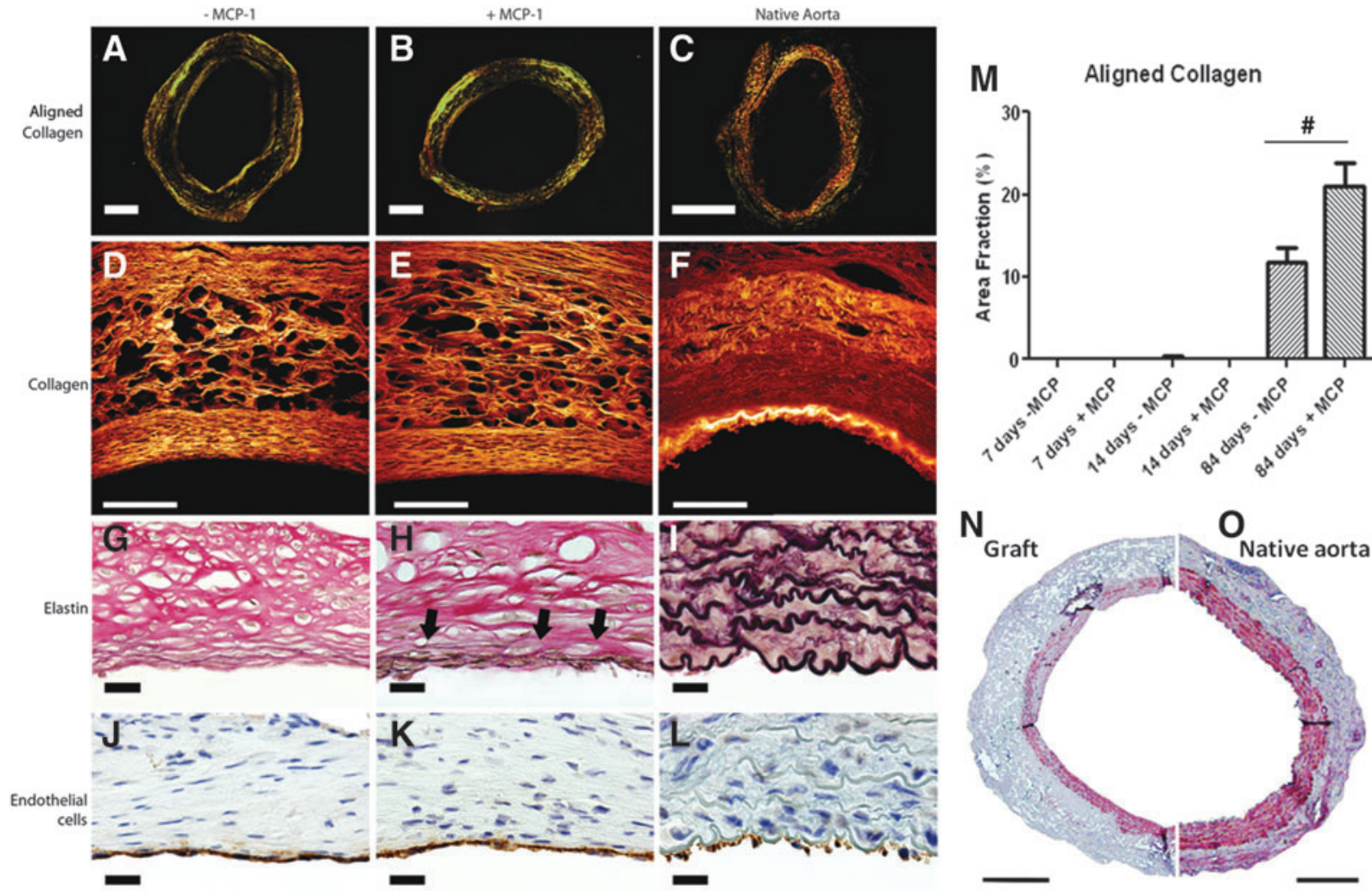

FIG. 7. 

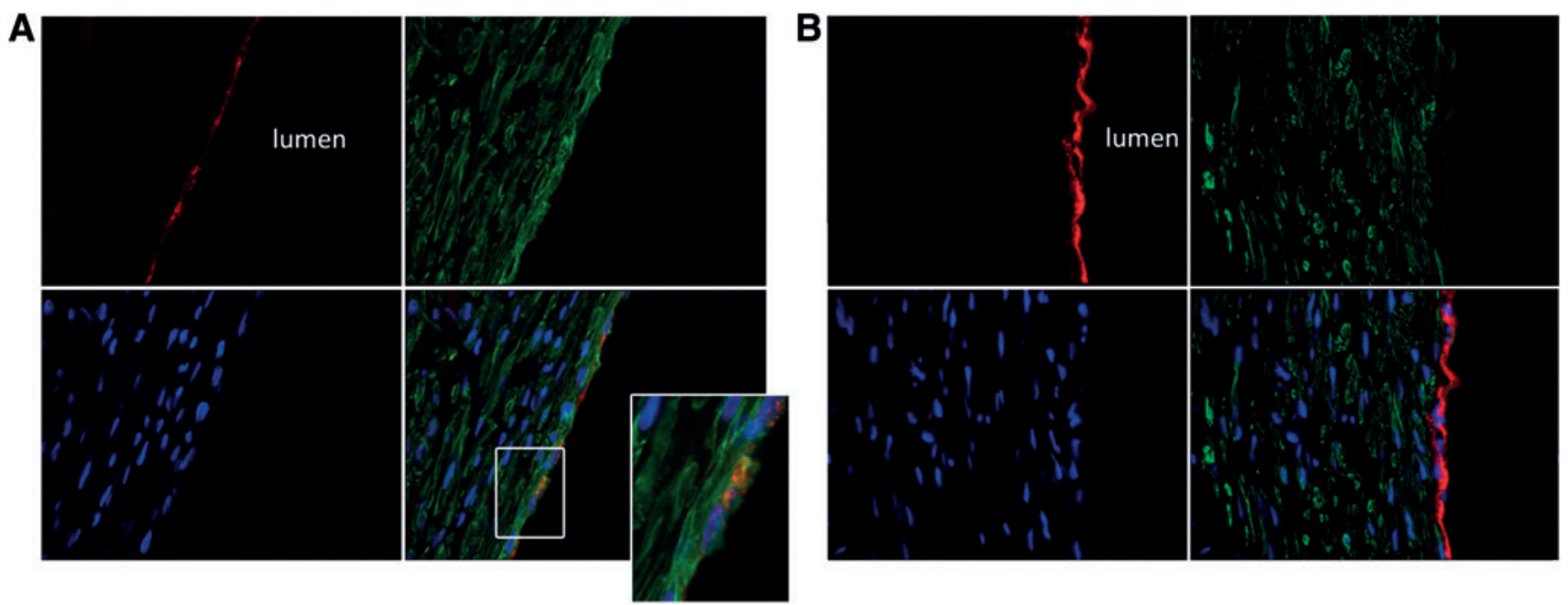

FIG. 8. Endothelial-to-mesenchymal transdifferentiation (EndoMT) analysis. Recruited ECs did not undergo EndoMT. Representative images at 14 (A) and 84 days (B) of immunofluorescent double staining of vWF (red) and aSMA (green) with cell nuclei in blue (DAPI). Rare colocalization of vWF and aSMA was detected (A, inset). Color images available online at www.liebertpub.com/tea

Macrophage function during inflammation and healing is governed by polarization state. ${ }^{33}$ Unexpectedly, we detected only very sparse expression of CD163, a typical surface marker for the M2 macrophage type that was reported in previous findings. ${ }^{9,14}$ However, on the gene level, we did observe indications, which suggest a shift in macrophage polarization in response to MCP-1 (Supplementary Fig. S2). Additionally, peripheral-derived macrophages have been shown to acquire myofibroblast-like characteristics during the foreign body response in rodents. ${ }^{34,35}$ The observed absence of coexpression of $\mathrm{vWF}$ and $\alpha$-SMA suggests that the process of endoMT was virtually absent during the in vivo time frame of the current study, implicating that the vast majority of $\alpha$ $\mathrm{SMA}^{+}$myofibroblasts did not originate from recruited ECs through endoMT. Taking into account that transmural and transanastomotic infiltration of mature SMCs was hampered, combined with the apparent absence of endoMT, it is plausible that the infiltrating blood-derived $\alpha-\mathrm{SMA}^{+}$cells descend directly from transdifferentiated macrophages.

In addition to peripheral leukocytes, circulating progenitor cells may contribute to vascular regeneration in terms of endothelialization as well as extracellular matrix production. Blood stream-derived cellularization of vascular grafts was proven in dogs, represented by patchy endothelial coverage with underlying $\alpha-\mathrm{SMA}^{+}$SMCs. ${ }^{36,37}$ Immunohistochemical characterization of infiltrated cells in our grafts demonstrates an increasing presence of $\mathrm{CD} 34^{+}$cells over time, with a significant upregulation in the MCP-1 group. CD34 is expressed by various circulating progenitor populations, including fibrocytes, which can differentiate into mature myofibroblasts upon activation by transforming growth factor- $\beta$ and through cross talk with macrophages. ${ }^{38,39}$ On the gene level, this coincided with a trend in upregulation of stromal cell-derived factor- $1 \alpha(\mathrm{SDF}-1 \alpha)$, which is a known attractant for $\mathrm{CD} 34^{+}$progenitor cells ${ }^{40}$ (Supplementary Fig. S2). MCP-1 has been shown to mobilize angiogenic monocytes, ${ }^{41-43}$ which may be responsible for the increased SDF- $1 \alpha$ expression and secondary recruitment of progenitors. The burst release of exogenous MCP-1 in the present study led to a remarkable effect on downstream events up to 3 months later, ignited by an increased early influx of leukocytes. Although the exact chain of events between the early and late-term observations in this study remains to be clarified, our results suggest that MCP-1-recruited monocytes/macrophages have a dual role; indirectly by creating a biochemical milieu favorable for attraction of secondary progenitor cells and directly through possible contribution of macrophage-to-myofibroblast transdifferentiation.

The rat model used in this study enables us to study the colonization of grafts by circulating cells, which is particularly relevant for the human situation. However, for clinical translation, it should be considered that the populations of specific cell types in the blood stream (e.g., monocyte subsets, progenitor cells) are highly variable between patients. Normal biological patient-to-patient variability as well as age and comorbidities will result in dissimilarities in the immunological and regenerative competence between patients. ${ }^{44-46}$ The use of the current methodology in a diseased animal model, in combination with mechanistic studies in human in vitro models, will be a valuable contribution to the understanding of the regenerative potential of circulating cells in various clinical settings.

In conclusion, the results of the current study prove the in situ regenerative potential of circulating cells in rats. In these conditions, relevant for the human situation, a short local burst of exogenous MCP-1 led to improved or at least accelerated neotissue formation and organization, with a layered structure of intimal endothelium and a medial layer of SMCs in an oriented collagen matrix with elastin fibers. These findings represent a valuable contribution in the clinical translation toward the development of safe and effective synthetic grafts for in situ tissue engineering.

\section{Acknowledgments}

The authors would like to thank Marc Simonet and Dr. Anand Nandakumar (Xeltis B.V.) for their contribution to the electrospinning of the tubular scaffolds. This research 
forms part of the iValve project of the research program of the BioMedical Materials institute cofunded by the Dutch Ministry of Economic Affairs. The financial contribution of the Nederlandse Hartstichting is gratefully acknowledged.

\section{Disclosure Statement}

No competing financial interests exist.

\section{References}

1. Nichols, M., Townsend, N., Scarborough, P., LuengoFernandez, R., Leal, J., Gray, A., et al. European Cardiovascular Disease Statistics 2012. Brussels: European Heart Network, and Sophia Antipolis: European Society of Cardiology, 2012.

2. Norgren, L., Hiatt, W., Dormandy, J., Nehler, M., Harris, K., and Fowkes, F. Inter-society consensus for the management of peripheral arterial disease (TASC II). J Vasc Surg 45 Suppl S, S5, 2007.

3. Peck, M., Gebhart, D., Dusserre, N., McAllister, T.N., and L'Heureux, N. The evolution of vascular tissue engineering and current state of the art. Cells Tissues Organs 195, 144, 2012.

4. Cleary, M., Geiger, E., Grady, C., Best, C., Naito, Y., and Breuer, C. Vascular tissue engineering: the next generation. Trends Mol Med 18, 394, 2012.

5. Mol, A., Smits, A.I.P.M., Bouten, C.V.C., and Baaijens, F.P.T. Tissue engineering of heart valves: advances and current challenges. Expert Rev Med Devices 6, 259, 2009.

6. Bouten, C.V.C., Dankers, P.Y.W., Driessen-Mol, A., Pedron, S., Brizard, A.M., and Baaijens, F.P.T. Substrates for cardiovascular tissue engineering. Adv Drug Deliv Rev 63, 221, 2011.

7. Mahler, G.J., and Butcher, J.T. Inflammatory regulation of valvular remodeling: the good(?), the bad, and the ugly. Int J Inflam 2011, 721419, 2011.

8. Van Loon, S.L.M., Smits, A.I.P.M., Driessen-Mol, A., Baaijens, F.P.T., and Bouten, C.V.C. The immune response in in situ tissue engineering of aortic heart valves. In: Aikawa, E., ed. Calcific Aortic Valve Disease. Rijeka: InTech, 2013, pp. 207-245.

9. Wu, W., Allen, R., and Wang, Y. Fast-degrading elastomer enables rapid remodeling of a cell-free synthetic graft into a neoartery. Nat Med 18, 1148, 2012.

10. Yokota, T., Ichikawa, H., Matsumiya, G., Kuratani, T., Sakaguchi, T., Iwai, S., et al. In situ tissue regeneration using a novel tissue-engineered, small-caliber vascular graft without cell seeding. J Thorac Cardiovasc Surg 136, 900, 2008.

11. Brennan, M.P., Dardik, A., Hibino, N., Roh, J.D., Nelson, G.N., Papademitris, X., et al. Tissue-engineered vascular grafts demonstrate evidence of growth and development when implanted in a juvenile animal model. Ann Surg 248, 370, 2008.

12. Mrówczyński, W., Mugnai, D., De Valence, S., Tille, J.C., Khabiri, E., Cikirikcioglu, M., et al. Porcine carotid artery replacement with biodegradable electrospun poly-ecaprolactone vascular prosthesis. J Vasc Surg 59, 210, 2014.

13. De Valence, S., Tille, J.-C., Mugnai, D., Mrowczynski, W., Gurny, R., Möller, M., et al. Long term performance of polycaprolactone vascular grafts in a rat abdominal aorta replacement model. Biomaterials 33, 38, 2012.

14. Hibino, N., Yi, T., Duncan, D.R., Rathore, A., Dean, E., Naito, Y., et al. A critical role for macrophages in neovessel formation and the development of stenosis in tissueengineered vascular grafts. FASEB J 25, 4253, 2011.
15. Roh, J.D., Sawh-Martinez, R., Brennan, M.P., Jay, S.M., Devine, L., Rao, D., et al. Tissue-engineered vascular grafts transform into mature blood vessels via an inflammationmediated process of vascular remodeling. Proc Natl Acad Sci U S A 107, 4669, 2010.

16. Van der Lei, B., Wildevuur, C.R., Nieuwenhuis, P., Blaauw, E.H., Dijk, F., Hulstaert, C.E., et al. Regeneration of the arterial wall in microporous, compliant, biodegradable vascular grafts after implantation into the rat abdominal aorta. Ultrastructural observations. Cell Tissue Res 242, 569, 1985.

17. Zhang, Z., Wang, Z., Liu, S., and Kodama, M. Pore size, tissue ingrowth, and endothelialization of small-diameter microporous polyurethane vascular prostheses. Biomaterials 25, 177, 2004.

18. Martakos, P., and Karwoski, T. Healing characteristics of hybrid and conventional polytetrafluoroethylene vascular grafts. ASAIO J 41, M735, 1995.

19. Hibino, N., Villalona, G., Pietris, N., Duncan, D.R., Schoffner, A., Roh, J.D., et al. Tissue-engineered vascular grafts form neovessels that arise from regeneration of the adjacent blood vessel. FASEB J 25, 2731, 2011.

20. Zilla, P., Bezuidenhout, D., and Human, P. Prosthetic vascular grafts: wrong models, wrong questions and no healing. Biomaterials 28, 5009, 2007.

21. Pennel, T., Zilla, P., and Bezuidenhout, D. Differentiating transmural from transanastomotic prosthetic graft endothelialization through an isolation loop-graft model. J Vasc Surg 58, 1053, 2013.

22. Robinson, P.H., Bartels, H.L., and van der Lei, B. Patency and healing of $10-\mathrm{cm}$ long microarterial polytetrafluoroethylene prostheses in the rat abdominal aorta. J Reconstr Microsurg 5, 331, 1989.

23. Clowes, A.W., Kirkman, T.R., and Reidy, M. Mechanisms of arterial graft healing. Rapid transmural capillary ingrowth provides a source of intimal endothelium and smooth muscle in porous PTFE prostheses. Am J Pathol 123, 220, 1986.

24. Golden, M.A., Hanson, S.R., Kirkman, T.R., Schneider, P.A., and Clowes, A.W. Healing of polytetrafluoroethylene arterial grafts is influenced by graft porosity. J Vasc Surg 11, 838, 1990.

25. Leprince, P., Rahmati, M., Bonnet, N., Bors, V., Rama, A., Léger, P., et al. Expanded polytetrafluoroethylene membranes to wrap surfaces of circulatory support devices in patients undergoing bridge to heart transplantation. Eur $\mathbf{J}$ Cardiothorac Surg 19, 302, 2001.

26. Wong, K.L., Yeap, W.H., Tai, J.J.Y., Ong, S.M., Dang, T.M., and Wong, S.C. The three human monocyte subsets: implications for health and disease. Immunol Res 53, 41, 2012.

27. Brancato, S.K., and Albina, J.E. Wound macrophages as key regulators of repair: origin, phenotype, and function. Am J Pathol 178, 19, 2011.

28. Willenborg, S., Lucas, T., van Loo, G., Knipper, J., Krieg, T., Haase, I., et al. CCR2 recruits an inflammatory macrophage subpopulation critical for angiogenesis in tissue repair. Blood 120, 613, 2012.

29. Shi, C., and Pamer, E.G. Monocyte recruitment during infection and inflammation. Nat Rev Immunol 11, 762, 2011.

30. Voskuil, M., van Royen, N., Hoefer, I.E., Seidler, R., Guth, B.D., Bode, C., et al. Modulation of collateral artery growth in a porcine hindlimb ligation model using MCP-1. Am J Physiol Heart Circ Physiol 284, H1422, 2003.

31. Ballotta, V., Smits, A.I.P.M., Driessen-Mol, A., Bouten, C.V.C., and Baaijens, F.P.T. Synergistic protein secretion 
by mesenchymal stromal cells seeded in 3D scaffolds and circulating leukocytes in physiological flow. Biomaterials 35, 9100, 2014.

32. Niu, J., and Kolattukudy, P.E. Role of MCP-1 in cardiovascular disease: molecular mechanisms and clinical implications. Clin Sci (Lond) 117, 95, 2009.

33. Smits, A.I.P.M., Ballotta, V., Driessen-Mol, A., Bouten, C.V.C., and Baaijens, F.P.T. Shear flow affects selective monocyte recruitment into MCP-1-loaded scaffolds. J Cell Mol Med 18, 2176, 2014.

34. Brown, B.N., Ratner, B.D., Goodman, S.B., Amar, S., and Badylak, S.F. Macrophage polarization: an opportunity for improved outcomes in biomaterials and regenerative medicine. Biomaterials 33, 3792, 2012.

35. Mooney, J.E., Rolfe, B.E., Osborne, G.W., Sester, D.P., van Rooijen, N., Campbell, G.R., et al. Cellular plasticity of inflammatory myeloid cells in the peritoneal foreign body response. Am J Pathol 176, 369, 2010.

36. Jabs, A., Moncada, G., Nichols, C.E., Waller, E.K., and Wilcox, J.N. Peripheral blood mononuclear cells acquire myofibroblast characteristics in granulation tissue. J Vasc Res 42, 174, 2005.

37. Shi, Q., Wu, M.H., Hayashida, N., Wechezak, A.R., Clowes, A.W., and Sauvage, L.R. Proof of fallout endothelialization of impervious Dacron grafts in the aorta and inferior vena cava of the dog. J Vasc Surg 20, 546, 1994.

38. Kouchi, Y., Onuki, Y., Wu, M.H., Shi, Q., Ghali, R., Wechezak, A.R., et al. Apparent blood stream origin of endothelial and smooth muscle cells in the neointima of long, impervious carotid-femoral grafts in the dog. Ann Vasc Surg 12, 46, 1998.

39. Mesure, L., De Visscher, G., Vranken, I., Lebacq, A., and Flameng, W. Gene expression study of monocytes/ macrophages during early foreign body reaction and identification of potential precursors of myofibroblasts. PLoS One 5, e12949, 2010.

40. Reilkoff, R., Bucala, R., and Herzog, E.L. Fibrocytes: emerging effector cells in chronic inflammation. Nat Rev Immunol 11, 427, 2011.
41. Chavakis, E., Urbich, C., and Dimmeler, S. Homing and engraftment of progenitor cells: a prerequisite for cell therapy. J Mol Cell Cardiol 45, 514, 2008.

42. Rehman, J., Li, J., Orschell, C.M., and March, K.L. Peripheral blood "endothelial progenitor cells" are derived from monocyte/macrophages and secrete angiogenic growth factors. Circulation 107, 1164, 2003.

43. Fujiyama, S., Amano, K., Uehira, K., Yoshida, M., Nishiwaki, Y., Nozawa, Y., et al. Bone marrow monocyte lineage cells adhere on injured endothelium in a monocyte chemoattractant protein-1-dependent manner and accelerate reendothelialization as endothelial progenitor cells. Circ Res 93, 980, 2003.

44. Seidler, S., Zimmermann, H.W., Bartneck, M., Trautwein, C., and Tacke, F. Age-dependent alterations of monocyte subsets and monocyte-related chemokine pathways in healthy adults. BMC Immunol 11, 30, 2010.

45. Jie, K.E., Goossens, M.H.J., van Oostrom, O., Lilien, M.R., and Verhaar, M.C. Circulating endothelial progenitor cell levels are higher during childhood than in adult life. Atherosclerosis 202, 345, 2009.

46. Shantsila, E., Wrigley, B.J., Shantsila, A, Tapp, L.D., Gill, P.S., and Lip, G.Y.H. Monocyte-derived and CD34+/KDR+ endothelial progenitor cells in heart failure. J Thromb Haemost 10, 1252, 2012.

Address correspondence to: Anthal I.P.M Smits, PhD Department of Biomedical Engineering Eindhoven University of Technology P.O. Box 513, $5600 \mathrm{MB}$ Eindhoven The Netherlands

E-mail: a.i.p.m.smits@tue.nl

Received: February 12, 2015

Accepted: July 9, 2015

Online Publication Date: August 24, 2015 